\title{
ACTIVITY PATTERNS OF BLACK BEARS IN RELATION TO SEX, SEASON, AND DAILY MOVEMENT RATES
}

\author{
Jesse S. Lewis ${ }^{1,2}$ and Janet L. Rachlow ${ }^{1}$
}

\begin{abstract}
Activity patterns of animals can vary depending on both endogenous and environmental factors. Although black bears exhibit substantial variation in activity across the year, relatively little is known about how daily activity patterns and associated movement rates differ among sex and age classes across seasons. We used fine-scale movement data from black bears fitted with GPS collars to evaluate movement and activity patterns across sex and age classes for daily and seasonal time periods in relation to mating and foraging behavior. Black bears were most active during crepuscular time periods, moderately active during the day, and least active at night, which is consistent with previous research on black bear activity patterns in areas where bears were not greatly influenced by human activities. However, during spring and early summer, adult males moved significantly more during the crepuscular time period than they did during late summer and fall. Female and subadult males exhibited very similar activity patterns between seasons; and during late summer and fall, all bear classes exhibited similar activity patterns across daily time periods. Differences in activity patterns of males between seasons were potentially related to extensive movements undertaken during the mating season. Although adult males exhibited lower movement rates in late summer and fall compared to spring and early summer, females and subadult males did not appear to reduce movement rates during the late-summer berry season. Our research reveals that, although bear classes exhibit similar temporal patterns of daily activity and inactivity, the magnitude of movement rates revealed differences in activity patterns among bear classes, which allowed us to better understand factors influencing activity in animal populations.
\end{abstract}

RESUMEN.-Los patrones de actividad de los animales pueden variar dependiendo, tanto los factores endógenos, como los ambientales. A pesar de que los osos negros exhiben gran variación en su actividad durante el año, se sabe relativamente poco acerca de cómo los patrones de actividad cotidiana y las tasas de movimientos asociados difieren entre los sexos y clases de edad a lo largo de las estaciones. Usamos datos de escala fina del movimiento de los osos negros, a través de collares con sistema de posicionamiento global (SPG), para evaluar los patrones de movimiento y actividad por sexo y por clases de edad, durante periodos de tiempo diarios y estacionales con relación al comportamiento de apareamiento y de forrajeo. Los osos negros fueron más activos durante los periodos de tiempo crepuscular; moderadamente activos durante el día y menos activos durante la noche, lo cual es consistente con las investigaciones previas en las que se evaluaban los patrones de actividad del oso negro en lugares donde no eran fuertemente influenciados por las actividades humanas. Sin embargo, durante la primavera y el comienzo del verano, los machos adultos se movieron significantemente más durante los periodos crepusculares, comparado con el final del verano y el otoño. Las hembras y los machos subadultos mostraron patrones de actividad muy similares entre las estaciones; y para finales del verano y el otoño, todas las clases de osos exhibieron patrones de actividad similares durante los periodos de tiempo diarios. Las diferencias en los patrones de actividad de los machos entre estaciones se relacionaron potencialmente a los extensos movimientos emprendidos durante la época de apareamiento. A pesar de que los machos adultos exhibieron tasas bajas de movimiento a finales del verano y en el otoño, en comparación con la primavera y principios del verano, las hembras y los machos subadultos no aparentaron disminuir las tasas de movimiento durante la época de bayas al final del verano. Nuestra investigación muestra que, a pesar de que las clases de osos exhiben patrones temporales similares de actividad e inactividad diaria, la magnitud de las tasas de movimiento reveló diferencias en los patrones de actividad entre las clases de osos, lo cual nos permitió entender mejor los factores que influyen en la actividad de las poblaciones de animales.

Activity patterns of animals are shaped by both endogenous (circadian or physiological rhythms) and environmental factors (Aschoff 1966, Nielsen 1983). Thus, activity patterns are influenced by fixed and plastic components, which presumably maximize the fitness, or survival and reproductive output, of the animal. As a result, organisms can demonstrate varying patterns of activity across temporal and spatial scales depending on environmental conditions, nutritional and reproductive status, and intraand interspecific interactions. Information on activity patterns can be used to understand how animals interact with their environment, including the influences of conspecifics, food resources, and anthropogenic factors.

${ }^{1}$ Department of Fish and Wildlife Resources, University of Idaho, Moscow, ID 83844

2Present address: Graduate Degree Program in Ecology, Department of Fish, Wildlife, and Conservation Biology, Colorado State University, Fort Collins, CO 80523. E-mail: jslewis@rams.colostate.edu 
Movements and activity patterns of American black bears (Ursus americamus) can vary depending on season, forage availability, gender, age, social interactions, and time of day (Garshelis and Pelton 1981, Young and Ruff 1982, Rogers 1987, Schwartz and Franzmann 1991, Powell et al. 1997, Samson and Huot 1998, Schwartz et al. 2010). In addition, human presence and behavior can strongly influence activity patterns of black bears. In areas where black bears avoid human food resources or do not experience substantial human disturbance, bears are most active during diurnal and crepuscular time periods and exhibit a bimodal pattern of activity (Amstrup and Beecham 1976, Lindzey and Meslow 1977, Ayres et al. 1986, Larivière et al. 1994, Beckman and Berger 2003). In contrast, in places where bears either exploit human food resources or are sufficiently disturbed by human activities, bears demonstrate greater activity during nocturnal time periods (Ayres et al. 1986, Beckman and Berger 2003, Matthews et al. 2006). Thus, black bears appear to demonstrate plasticity in their activity patterns and adapt their movements in response to their environment, including anthropogenic sources of disturbance.

Previous studies quantifying activity of black bears interpreted signal patterns from very high frequency (VHF) collars with activity switches that emit a different signal when the collar is moving. Activity switches on GPS collars have also been used to evaluate activity of black bears in a similar fashion. These data effectively discriminate between resting and active bears (Lindzey and Meslow 1977, Garshelis and Pelton 1980, Ayres et al. 1986, Larivière et al. 1994, Matthews et al. 2006, Schwartz et al. 2010); however, the magnitude of activity or rate of movement cannot be evaluated using these methods. Therefore, although 2 individuals might demonstrate identical binary activity patterns (i.e., active or inactive), they could exhibit marked differences in behaviors and movements during active periods. For example, an animal would be classified as active if it moved $0 \mathrm{~m}$ and was grooming itself or if it was traveling at a rapid pace across the landscape. Thus, our understanding of activity patterns of animals would be advanced by measuring activity on a continuous scale of movement to understand the magnitude of activity across daily and seasonal time periods. GPS collars can record locations at frequent time intervals throughout daily time periods, enabling researchers to evaluate finer-scale patterns of animal movements and the magnitude of activity.

Our objective was to evaluate fine-scale movements for black bears across sex and age classes during daily and seasonal time periods to understand how humans, the bear mating season, and seasonally available food resources influence activity patterns. If bears were habituated to human foods, we expected animals to be most active at night; and if bears were not habituated to human foods, we predicted that animals would exhibit a bimodal daily activity pattern, with animals being most active during crepuscular time periods. We expected that the activity patterns of bears in this study would be consistent with patterns of habitat selection where bears avoided areas of human development, as demonstrated in previous studies. If activity patterns were driven by the mating season, we expected adult males to increase movement rates when they engaged in mateseeking behavior during spring and early summer, and we predicted that other age-sex classes would not demonstrate different movement patterns between seasons. If activity patterns were driven by the presence of seasonally available berries in late summer and fall, then we expected that movement rates for all bear classes would decline during the berry season compared to the nonberry season, because bears would concentrate foraging behavior within berry patches and exhibit more continuous activity throughout the day. If both the mating and berry seasons influenced bear movements, then we expected both of the patterns described above to be evident.

\section{Methods}

\section{Study Area}

The study area was located in the Purcell Mountains of northeastern Idaho, USA, and southern British Columbia, Canada (Fig. 1; $116^{\circ} 16^{\prime} \mathrm{W}, 48^{\circ} 57^{\prime} \mathrm{E}$ ). The $1200-\mathrm{km}^{2}$ study area was bordered to the west by the Kootenai River, to the north by Highway 3 in Canada, to the east by the Montana state line, and to the south by Highway 2 in Idaho. U.S. Highway 95 , many paved and graveled county roads, and dirt forest roads occur within the study area. Topography of the area is varied, ranging from broad valley bottoms to steep and broken 


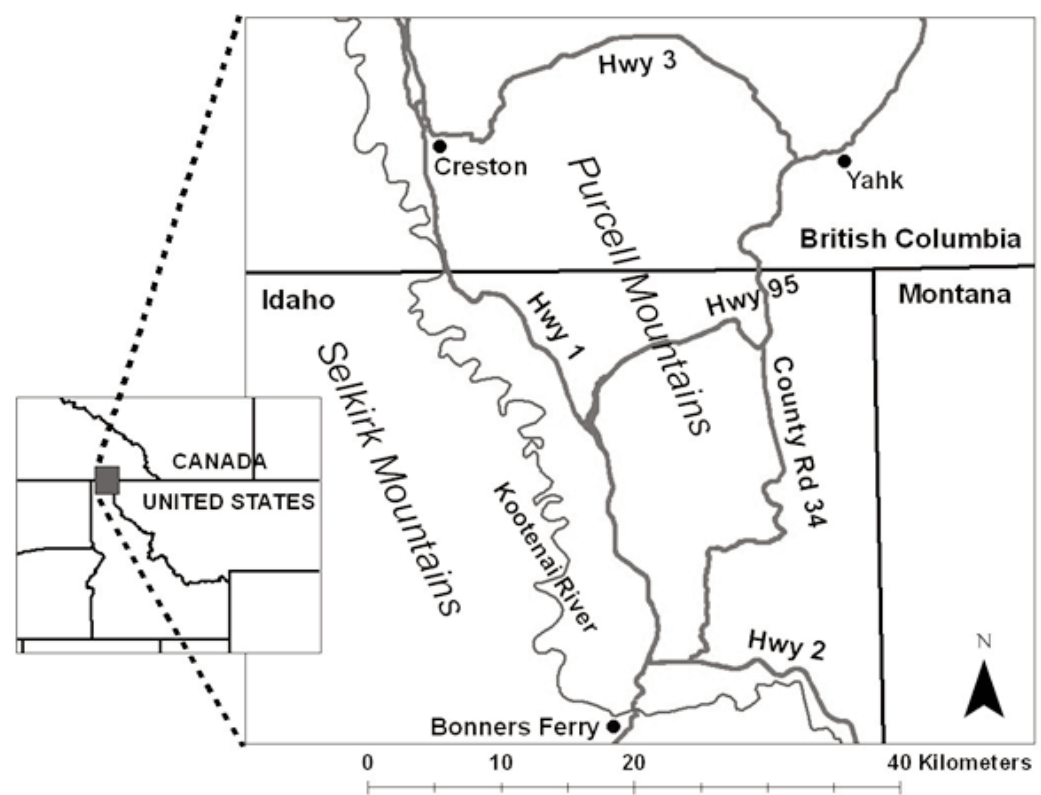

Fig. 1. Study area where movement rates and activity patterns of black bears were evaluated in the Purcell Mountains of northern Idaho, USA, and southern British Columbia, Canada, 2005-2006.

mountain slopes, with elevations from $700 \mathrm{~m}$ to $>1900 \mathrm{~m}$. The regional climate is Pacific maritime with cold, snowy winters and warm summers. Annual precipitation averaged 100$150 \mathrm{~cm}$, mostly as snow (Kasworm et al. 2007). Forest dominated the study area, although extensive open areas were present in meadow sites and in areas of recent timber harvest. Common tree species included ponderosa pine (Pinus ponderosa), Douglas-fir (Pseudotsuga menziesii), western red cedar (Thuja plicata), western hemlock (Tsuga heterophylla), subalpine fir (Abies lasiocarpa), Engelmann spruce (Picea engelmannii), and lodgepole pine (Pinus contorta). Huckleberries (Vaccinium sp.) and buffaloberries (Shepherdia canadensis) were prevalent throughout the study area from mid- to upper elevations. Land ownership was mostly USDA Forest Service, although small areas belonging to private timber companies were present. Land bordering highways was mostly private and included human residences. Extensive agricultural fields were present on the western side of the study area in the Kootenai Valley.

\section{Animal Capture}

We trapped bears from June to mid-August in 2004-2006 using Aldrich foot snares (Johnson and Pelton 1980). Immobilization was achieved with a Telazol/Xylazine combination and Xylazine was reversed with either Yohimbine or Tolazoline. We monitored bear health, administered oxygen, and recorded body measurements. When necessary, a tooth was extracted for age determination (Matson's Laboratory LLC, Milltown, MT; Stoneberg and Jonkel 1966). Lotek 3300L GPS collars with cotton spacers were fitted on all bears weighing more than $35 \mathrm{~kg}$. The weight requirement ensured that the collar weight did not exceed $2.5 \%$ of the body weight of an outfitted bear. Collars were programmed to record a location every 20 minutes from April (den emergence) to November (den entrance), and information was stored on the collar. Each winter (2005-2007), we visited bear dens to retrieve and replace GPS collars. Methods were approved by the University of Idaho Animal Care and Use Committee (Protocol 2005-27).

\section{Screening Location Data}

To increase the accuracy of the GPS location data used in our analyses, we retained all 3dimensional fixes and screened out 2-dimensional fixes with a Positional Dilution of Precision $(\mathrm{PDOP})>5$, because this approach was most efficient at removing relatively large location 
errors while eliminating the fewest number of accurate locations and retaining a relatively large proportion of the original successful fixes (Lewis et al. 2007). Because potentially large location errors were purged from the data set and only a small amount of additional data were screened, we believe that we more accurately measured movement rates. Overall data retention for black bear GPS data sets was about $84 \%$ (Lewis et al. 2007).

\section{Movement Rates}

We evaluated activity of bears from April to November in 2005 and 2006. We calculated the mean distance traveled (based on distance between successive locations, or step length) per 20 minutes for hourly time periods within a day. When a location was missing, we divided the step length by the actual time interval between successful fixes to calculate movement rate relative to 20 minutes. For example, if an animal traveled $300 \mathrm{~m}$ in 40 minutes, then we recorded the step length as $150 \mathrm{~m}$. This approach produced a conservative estimate because the animal most likely did not travel in a straight line during the entire time period. To calculate movement rates we grouped bears into 3 sex and age categories (adult males, subadult males, and females) and used the individual bear as the sampling unit within seasonal comparisons.

We evaluated movement patterns across seasons and daily time periods. The time of year when bears were active was divided into 2 seasons based on the phenology of berryproducing shrubs and the mating season: spring/ early summer when berries were generally not available (den emergence, generally late April or early May to 15 July) and late summer/fall when berries were present (16 July to den entrance, generally mid- to late October). The mating season occurs during spring and early summer and is generally completed by late July. The daily hours were broken into four 6-hour periods: day (10:00-16:00), night (22:004:00), morning crepuscular (4:00-10:00), and evening crepuscular (16:00-22:00). The mean movement rates were calculated for each animal during each of the 4 daily time periods by averaging values during the 3 middle hours that characterized each temporal period. An analysis of variance approach (PROC MIXED, SAS Institute) was used to evaluate differences in movement rates for full models among daily time periods, between seasons across daily time periods, and among bear classes across daily time periods during both seasons. The individual bear was defined as a random variable in modeling procedures. Contrast statements (PROC GLIMMIX, SAS Institute) tested specific a priori comparisons of movement rates among bear classes. Specifically, we evaluated whether adult males exhibited different movement rates compared to both females and subadult males during daily time periods and whether bear classes exhibited different activity patterns between seasons. We also conducted 2 a posteriori contrast statements to evaluate movement rates of adult males versus subadult males and adult males versus females during the crepuscular time period in spring/early summer. Because our hypotheses focused on comparisons during times of peak activity, the morning and evening crepuscular time periods were grouped into a single crepuscular period for analyses. Due to unequal variance in movement rates among different times of day (e.g., lower variance in movement rates was expected at night compared to crepuscular time periods), a log transformation was applied to the response variable of movement rate to create an appropriate pattern of residuals. Our sampling units were individual bears during each season. If a bear was sampled for $>1$ year, then we used only one data set for a given season for that individual and chose the seasonal period with the greatest number of GPS locations.

\section{RESUlTS}

We obtained data sets for 24 black bears and were able to evaluate fine-scale movements for 6 adult males, 6 subadult males, and 5 females during spring/early summer and 9 adult males, 5 subadult males, and 4 females during late summer/fall. Mean movement rates ranged from about $40-140 \mathrm{~m}$ and $40-180 \mathrm{~m}$ per 20-minute interval throughout the day for females and males, respectively. Across all sex classes, age classes, and seasons, bear movement rates peaked during crepuscular time periods, were moderate during the day, and were relatively low at night (Fig. 2). Differences in movement rates across daily time periods for all bears were significant during both spring/early summer $\left(F_{3,48}=276.82, P\right.$ $<0.0001)$ and late summer/fall $\left(F_{3,54}=99.69\right.$, $P<0.0001)$. Black bears were active starting 

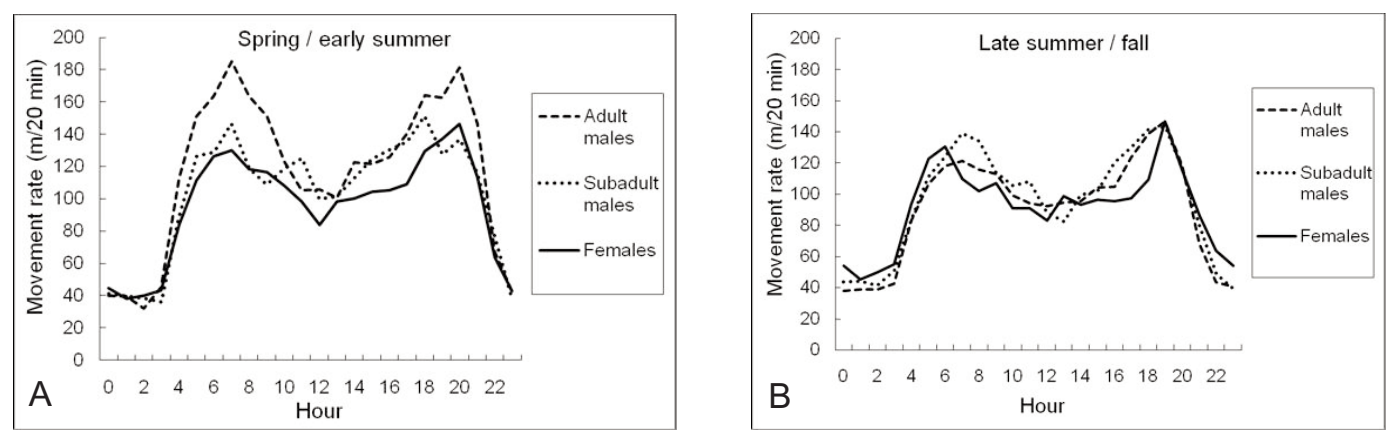

Fig. 2. Mean distance (m) traveled per 20 minutes by black bears for adult males, subadult males, and females during (A) spring/early summer (mating season, but berries generally not present) and (B) late summer/fall (berries present) in the Purcell Mountains of northern Idaho, USA, and southern British Columbia, Canada, 2005-2006.

TABLE 1. Comparison of movement rates between adult male and female/subadult male black bears across daily time periods and seasons in the Purcell Mountains, Idaho, USA, and British Columbia, Canada. Contrast statements were used to evaluate differences in daily activity patterns between adult males and both females and subadult males.

\begin{tabular}{|c|c|c|c|c|c|c|}
\hline \multirow[b]{2}{*}{ Daily time period } & \multicolumn{3}{|c|}{ Spring/early summer } & \multicolumn{3}{|c|}{ Late summer/fall } \\
\hline & $\mathrm{df}$ & $t$ & $P$ & $\mathrm{df}$ & $t$ & $P$ \\
\hline Crepuscular & 59.33 & 2.49 & 0.016 & 51.11 & -0.10 & 0.922 \\
\hline Day & 95.26 & 0.42 & 0.677 & 87.87 & 0.40 & 0.692 \\
\hline Night & 95.26 & -1.08 & 0.285 & 87.87 & -1.43 & 0.156 \\
\hline
\end{tabular}

at about 4:00 and became inactive at about 22:00.

Daily patterns of movement differed among bear classes and between seasons. Only adult males altered daily activity patterns between seasons: during crepuscular periods, mean movement rates (distance per 20-minute step) declined from $170.0 \mathrm{~m}(\mathrm{SE}=5.4)$ in spring/ early summer to $126.4 \mathrm{~m}(\mathrm{SE}=12.1)$ in late summer/fall $(t=3.51, \mathrm{df}=100.9, P=0.0007)$. However, movement rates during the night and day remained similar between seasons (Fig. 2). Movement rates were very similar between seasons for females $(t=0.28, \mathrm{df}=$ $101.5, P=0.777)$ and subadult males $(t=0.44$, $\mathrm{df}=111.4, P=0.664$; Fig. 2). During spring/ early summer, subadult males and females exhibited similar activity patterns, but adult males exhibited greater movement rates during crepuscular time periods than subadult males and females collectively (Fig. 2a, Table 1). In addition, during the crepuscular time period in spring/early summer, a posteriori contrast statements demonstrated that adult males exhibited significantly greater movement rates than subadult males $(t=2.25, \mathrm{df}=53.02, P=0.028)$ and marginally significant greater movement rates than females $(t=1.97, \mathrm{df}=61.85, P=0.053)$. However, movement rates among bear classes during spring/early summer for crepuscular periods demonstrated overlapping 95\% confidence intervals between adult males and females, but nonoverlapping 95\% confidence intervals between adult and subadult males. In spring and early summer, the mean movement rate during the crepuscular time period was $170.0 \mathrm{~m}(\mathrm{SE}=5.4)$ for adult males, $128.7 \mathrm{~m}$ $(\mathrm{SE}=11.2)$ for subadult males, and $131.4 \mathrm{~m}$ (SE $=20.1$ ) for females. In contrast, during late summer/fall, bears in all sex and age classes exhibited similar movement patterns across all daily time periods (Fig. 2b, Table 1). During both seasons and across all bear classes, the greatest variance of movement rates among individuals was observed during the crepuscular time periods and the least variance among individuals was observed during the night.

\section{Discussion}

Black bears demonstrated varying patterns of activity throughout daily time periods and between seasons. In general, movement rates by black bears were greatest during morning 
and evening, moderate during diurnal time periods, and lowest at night, which was consistent with our expectation that this population was not habituated to human food resources (Amstrup and Beecham 1976, Lindzey and Meslow 1977, Ayres et al. 1986). These results are also supported by habitat selection analyses in our study area, which demonstrated that bears avoided areas of human development on both broad and fine spatial scales (Lewis 2007, Lewis et al. 2011). Our use of animal locations from GPS collars permitted quantification of the magnitude to which bears were active throughout the day based on movement rates. This finer-scale information revealed differences in activity levels among bear classes that exhibited similar active/inactive patterns. For example, only adult male black bears demonstrated greater movement rates during spring and early summer compared to late summer and fall. Movement rates of adult males, however, were only different during the crepuscular time periods in spring and early summer, and were similar to activity patterns of subadult males and females during late summer and fall (Fig. 2, Table 1).

The greater movement rates of adult males in spring and early summer is likely related to strategies to maximize their fitness. We describe 2 possible explanations for the elevated movement rates exhibited by adult male black bears. First, higher rates of movement for adult males during spring and early summer might be related to mate-seeking behavior. Males demonstrated peaked activity when females were most active during crepuscular time periods. During this time, males also moved greater distances, possibly demonstrating increased activity levels when competing with other males to locate and breed with females while they were receptive. During late summer, the mating season is mostly over. Adult males decreased their movement rates during this period and exhibited movement rates similar to females and subadult males. Studies in the eastern United States (Garshelis and Pelton 1980) and western Canada (Young and Ruff 1982) also indicated that activity levels of black bears peaked in spring and summer, which was possibly related to breeding activity. A second possible explanation for the differences in movement rates among bear classes between seasons involves the presence of berries on fruiting shrubs during late summer and fall. Berries likely represent a food resource that is more concentrated than succulent green vegetation is in the spring, and bears foraging within a productive berry patch might move relatively short distances while accessing this food. Adult males might generally move greater distances to maintain a larger home range than other bear classes; however, when food is concentrated on the landscape, males could fulfill their daily and seasonal nutritional requirements by moving shorter distances throughout the day. Females and subadult males did not shift their activity patterns between seasons; potentially, the smaller body sizes of these bears influenced their activity levels, such that they exhibited foraging behaviors different from those of adult males.

Although berries on fruit-producing shrubs comprise over $90 \%$ of black bear diets in the region during late summer (Kasworm and Manley 1988, Kasworm and Their 1993), movement rates did not consistently decrease across bear classes when bears focused foraging activity on this food resource. However, black bears may dramatically alter activity patterns between years in response to berry production. For example, during years of average berry production, black bears near Aspen, Colorado, exhibited activity patterns similar to those observed in our study (Buroch-Murdo unpublished data). In contrast, during years of lowerthan-average berry production in Colorado, bears altered their activity patterns to be more nocturnal, and they fed on human food resources near urban areas, demonstrating substantial plasticity in activity patterns between years depending on seasonally available forage. The production of huckleberries was similar and average for both years of our study (Kasworm et al. 2007); thus, we do not believe that bears demonstrated altered activity and movement patterns, as might be observed during years when berry production fails. During years that the berry crops are below average in our study area, however, we expect that bears would exhibit greater activity during the nocturnal time period and potentially exploit available human food resources.

We present 3 considerations for interpreting results of bear activity patterns in our study. First, black bear activity patterns might be shaped by additional ecological factors that we did not consider in our hypotheses. For example, black bears prey on ungulate neonates during the spring (Zager and Beecham 2006), 
but it was unknown whether this predation was a significant occurrence in our study area. Although grizzly bears (Ursus arctos) appear to alter their behavior in spring to search for ungulate neonates (French and French 1990), it is unclear to what degree such searching behavior is included in the activity patterns of black bears. Second, activity patterns of black bears could be shaped by interspecific interactions. In Teton National Park, Wyoming, black bears altered their activity patterns and became more active during the day where they were sympatric with grizzly bears (Schwartz et al. 2010). At least a few grizzly bears were present in our study area, although we do not have sufficient data to evaluate how interactions with grizzly bears potentially influenced activity patterns of black bears. Lastly, in our study, although adult and subadult males demonstrated significant differences between their activity levels in spring and early summer during crepuscular time periods, it was less clear, likely due to a relatively small number of females in our study, whether adult males and females exhibited different movement rates during this time period. The higher variance in female movement rates during the crepuscular time period of the breeding season indicated potential differences among individuals. Future research could compare activity patterns of subadult females, adult females with cubs, adult females with yearlings, and adult females without dependent young to better understand movement patterns among female classes across seasons.

We were able to characterize bear activity on a fine scale by evaluating rates of movement, in contrast to defining behavior as binary (i.e., either active or inactive). Thus, we were able to evaluate potential differences in activity among bear classes within a day and between seasons. Although our results appear to be most consistent with the hypothesis that mate-seeking behavior most strongly influences activity patterns during years of average berry production, additional research is necessary to understand how varying levels of available forage, or additional ecological factors, might alter black bear activity patterns and movements across bear classes. Indeed, there is evidence that black bear population dynamics can be affected by berry production in our study area (McCall 2009). In addition, future research could link bear activity more closely to behavior. For example, periods of measured low movement rates could be related not to resting but to foraging within a confined area where bears move very little, such as at a productive berry patch or at an animal carcass. Understanding how ecological processes influence activity patterns of animals (e.g., Munro et al. 2006) is an interesting and important topic of further study, which will assist us in understanding how animals respond to human and environmental factors.

\section{ACKNOWLEDGMENTS}

Funding, support, and assistance for this project were provided by the Idaho Department of Transportation, Idaho Department of Fish and Game, U.S. Fish and Wildlife Service, USDA Forest Service, and University of Idaho. We thank W. Wakkinen, J. Hayden, P. Zager, D. Davis, M. Hartz, W. Kasworm, T. Radandt, M. Proctor, T. Johnson, B. Holt, B. McCall, M. Drew, B. Johnson, G. Johnson, B. Lyndaker, J. Knetter, D. Spicer, E. Bender, C. Walker, C. Servheen, H. Carilles, J. Beecham, P. Chapman, and many others for providing tremendous support, assistance with the project and fieldwork, and discussions about our research. Helpful comments and critique that improved this manuscript were provided by O. Garton, L. Vierling, P. Zager, and 2 anonymous reviewers.

\section{Literature Cited}

Amstrup, S.C., AND J.J. BeECHam. 1976. Activity patterns of radio-collared black bears in Idaho. Journal of Wildlife Management 40:340-348.

AschofF, J. 1966. Circadian activity pattern with two peaks. Ecology 47:657-662.

Ayres, L.A., L.S. Chow, And D.M. Graber. 1986. Black bear activity patterns and human induced modifications in Sequoia National Park. International Conference on Bear Research and Management 6:151-154.

Beckman, J.P., AND J. BERGER. 2003. Rapid ecological and behavioural changes in carnivores: the responses of black bears (Ursus americanus) to altered food. Journal of Zoology (London) 261:207-212.

French, S.P., AND M.G. FrenCH. 1990. Predatory behavior of grizzly bears feeding on elk calves in Yellowstone National Park, 1986-1988. International Conference on Bear Research and Management 8:335-341.

Garshelis, D.L., AND M.R. PELTON. 1980. Activity of black bears in the Great Smoky Mountains National Park. Journal of Mammalogy 61:8-19.

1981. Movements of black bears in the Great Smoky Mountains National Park. Journal of Wildlife Management 45:912-925.

Johnson, K.G., and M.R. Pelton. 1980. Prebaiting and snaring techniques for black bears. Wildlife Society Bulletin 8:46-54. 
Kasworm, W.F., H. Carriles, T.G. Radandt, and C. Servheen. 2007. Cabinet-Yaak Grizzly Bear Recovery Area 2006 Research and Monitoring Progress Report. U.S. Fish and Wildlife Service, Missoula, MT.

KaswORM, W.F., AND T.L. Manley. 1988. Grizzly bear and black bear ecology in the Cabinet Mountains of northwest Montana. Contract Report, Montana Department of Fish, Wildlife, and Parks, Helena, MT. 122 pp.

Kasworm, W.F., and T.J. Their. 1993. Cabinet-Yaak Ecosystem Grizzly Bear and Black Bear Research 1992 Progress Report. U.S. Fish and Wildlife Service, Missoula, MT. 76 pp.

LARIVIÈRE, S., J. HuOT, AND C. SAMSON. 1994. Daily activity patterns of female black bears in a northern mixed-forest environment. Journal of Mammalogy 75:613-620.

LEWIS, J.S. 2007. The effects of human disturbance on black bear habitat selection and movement patterns within a highway corridor. Master's thesis, University of Idaho, Moscow, ID.

Lewis, J.S., J.L. Rachlow, E.O. Garton, and L.A. VierLING. 2007. Effects of habitat on GPS collar performance: using data screening to reduce location error Journal of Applied Ecology 44:663-671.

Lewis, J.S., J.L. Rachlow, J.S. Horne, E.O. Garton, W.L. Wakkinen, J. Hayden, AND P. Zager. 2011 Identifying habitat characteristics to predict highway crossing areas for black bears within a humanmodified landscape. Landscape and Urban Planning 101:99-107.

Lindzey, F.G., AND E.C. MEsLow. 1977. Home range and habitat use by black bears in southwestern Washington. Journal of Wildlife Management 41:413-425.

Matthews, S.M., J.J. Beecham, H. Quigley, S.S. GreenLEAF, AND H.M. LEITHEAD. 2006. Activity patterns of American black bears in Yosemite National Park. Ursus $17: 30-40$

MCCALL, B.S. 2009. Noninvasive genetic sampling reveals black bear population dynamics driven by changes in food productivity. Master's thesis, University of Montana, Missoula, MT.
Munro, R.H.M., S.E. Nielsen, M.H. Price, G.B. StenHouse, AND M.S. Boyce. 2006. Seasonal and diel patterns of grizzly bear diet and activity in west-central Alberta. Journal of Mammalogy 87:1112-1121.

Nielsen, E.T. 1983. Relation of behavioural activity rhythms to the changes of day and night: a revision of views. Behaviour 89:147-173.

Powell, R.A., J.W. Zimmerman, and D.E. Seaman. 1997. Ecology and behaviour of North American black bears: home ranges, habitat, and social organization. Chapman and Hall, London, United Kingdom.

ROGERS, L.L. 1987. Effects of food supply and kinship on social behavior, movements, and population growth of black bears in northwestern Minnesota. Wildlife Monographs 97:1-72.

Samson, C., AND J. Huot. 1998. Movements of female black bears in relation to landscape vegetation type in southern Quebec. Journal of Wildlife Management 62:718-727.

SChWARTZ, C.C., AND A.W. FranZmann. 1991. Interrelationship of black bears to moose and forest succession in the northern coniferous forest. Wildlife Monographs 113:1-58.

Schwartz, C.C., S.L. Cain, S. Podruzny, S. Cherry, and

L. Frattaroli. 2010. Contrasting activity patterns of sympatric and allopatric black and grizzly bears. Journal of Wildlife Management 74:1628-1638.

Stoneberg, R.P., And C.J. Jonkel. 1966. Age determination of black bears by cementum layers. Journal of Wildlife Management 30:411-414.

Young, B.F., AND R.L. RuFf. 1982. Population dynamics and movements of black bears in east central Alberta. Journal of Wildlife Management 46:845-860.

ZaGer, P., AND J. BEECHAM. 2006. The role of American black bears and brown bears as predators on ungulates in North America. Ursus 17:95-108.

Received 2 April 2010 Accepted 10 May 2011 